International Journal of Solar Thermal

Vacuum Engineering

\title{
Effect of hot-arid climatic solar energy on monocrystalline photovoltaic performance in Pakistan
}

\author{
Asif Khan ${ }^{1}$, Saim Memon ${ }^{1, *}$ \\ Solar Thermal Vacuum Engineering Research Group, London Centre for Energy Engineering, School of Engineering, London South Bank \\ University, London, United Kingdom
}

\begin{abstract}
The domestic dwellings in Pakistan have predominantly implemented low-carbon strategies by harvesting solar energy using photovoltaic (PV) panels as a long-term vision of low-carbon economy. Most of the urban areas in Pakistan stay hot and humid in an entire year. Consistent solar irradiation at higher temperatures is one of the major factors that affect the power generation performance of monocrystalline PV systems pose challenges to performance and degradation issues. Monocrystalline PV module efficiencies are declining and damaging under the continuous exposure to higher surface day-time temperatures in the different parts of the country. MATLAB simulations were performed based on the validated mathematical approach. This paper investigates the hot arid surface temperature impacts on the performance of PV modules during the summer and winter seasons in Pakistan. The investigations are performed examining the comparative output power generating performance of the PV system. This paper also investigates the influence of installations of PV-system in the North, South, East and West regions of Pakistan. It was examined that the northern areas of Pakistan are more suitable for maintaining the long-term durability of the PV system. Investigations are performed for the peak summer and peak winter days. During summer months, cooling strategies have to be implemented to overcome the heating effects whilst reducing degradation effect on installed PV-system.
\end{abstract}

Keywords:

photovoltaic; monocrystalline; solar energy; hot-arid climate; Pakistan; MATLAB simulations.

Copyright $\odot 2020$ PENERBIT AKADEMIA BARU - All rights reserved

\section{Introduction}

Substantial efforts in tackling the energy shortage are being applied with the rollout of Photovoltaic (PV) panels in all regions of Pakistan in reducing the carbon emissions [1-2] with a drive towards the sustainable smart cities as a developing country. It is well-known that electrical energy demand in Pakistan is consistently increasing imposing fuel poverty in rural areas, so far, a shortage of $4000 \mathrm{MWh}$ in Pakistan causing many hours of load-shading and damaging the economic growth [3-4]. Most of the urban areas are suffering through 10-12 hours of power load-shedding. In rural areas, the load-shedding occur between 16 and 18 hours a day [5]. The energy generation from conventional sources has already been identified as insufficient in overcoming the energy demand and growing population. The utilisation of a large amount of fossil fuel produces the carbon emissions resulting climate-change $[6,7]$. To reduce this effect, renewable energy resources are one of the

\footnotetext{
* Corresponding author.

E-mail address: $\underline{\text { S.Memon@Isbu.ac.uk }}$
}

https://doi.org/10.37934/stve.2.1.1939 
solutions $[8,9]$. Among renewable energy, PV integrated buildings play a significant part, because buildings are responsible of over $60 \%$ of total energy consumption [10-12]. In which, vacuum insulation [13-15] and translucent photovoltaic films integration to vacuum insulation panel [16-17] are a few of progressive technologies that could enhance the buildings insulation properties whilst also benefitting from the overall reduction of energy bills. However, vacuum insulated panel or vacuum glazing are still developmental technologies [18] due to the limitations of the cost of materials [19,20], laser sealing [21,22], temperature induced stresses [23], longevity or stability of vacuum pressure $[24,25]$ and control of solar heat gains [26-28] with photovoltaic films are current challenges. The installations of PV panels in the domestic buildings of Pakistan are relatively new and are growing faster due to greater benefits of shunning the energy supply-demand gap [29]. In recent years, Pakistan shifted its environmental and energy policies towards sustainable and renewable energy economic policies. Due to this, a large number of PV systems are being implemented across the country [30-31]. The PV systems installed are of two types, on-grid and off-grid systems [32]. In the grid-connected system PV panels are connected directly to the grid by using DC/AC power electronics converters $[33,34]$. The major component to convert the DC generated power into AC power with required voltage is the inverter. Maximum power point tracking (MPPT) algorithm makes PV units capable of generating the power at full capacity. It does not move the panel towards sun to extract power instead it varies the electrical properties of the PV panel for achieving the maximum power and improving the efficiency of the PV panel by maintaining the voltage and current at an appropriate level. MPPT calculates energy values to apply the correct duty cycle to achieve the required results. It is typically suitable for charging up battery banks because it increases the efficiency of battery charging rate. The off-grid system is autonomous and is not connected to the grid. [35-37].

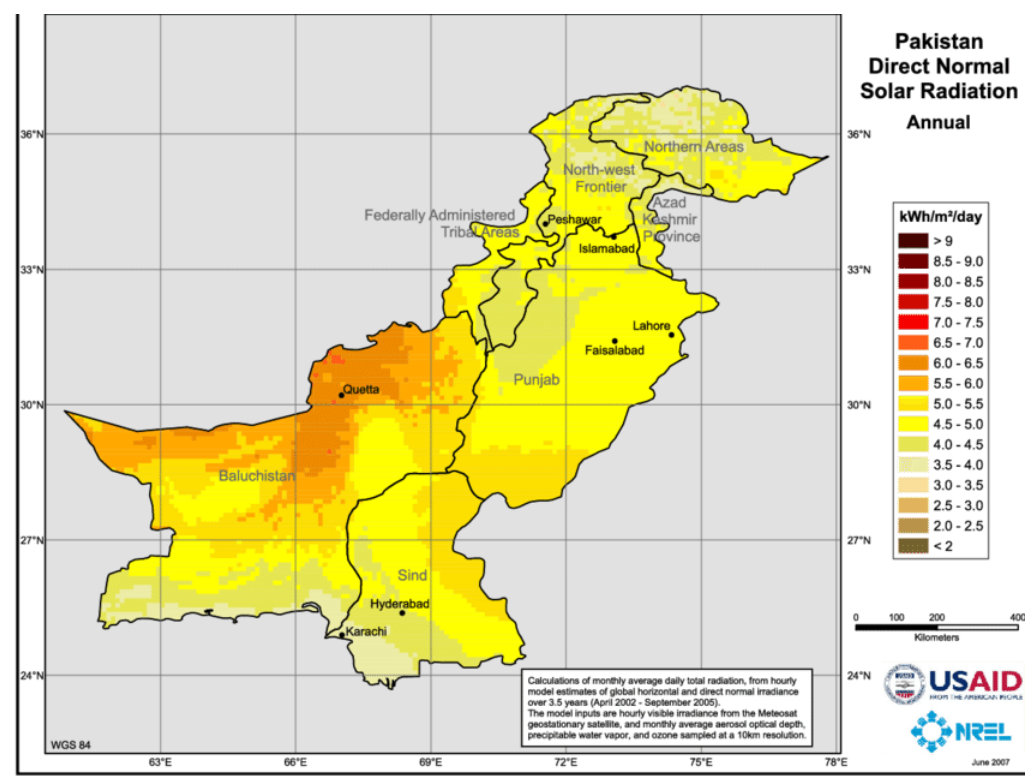

Fig. 1. Pakistan annual direct solar radiations [44]

A recent study shows the results obtained from the 69 metrological stations over the recent 30 years period that the more than $70 \%$ area of Pakistan receives an average yearly solar irradiation of $5.5 \mathrm{kWh} / \mathrm{m}^{2} /$ day as shown in Fig.1 [38]. The data collected by the Pakistan metrological department for the five major cities of Pakistan show that the west of Pakistan (Quetta) located in Baluchistan receives $21.6 \mathrm{MJ} / \mathrm{m}^{2} /$ day. The annual average in other cities of Pakistan such as: Lahore receives $19.25 \mathrm{MJ} / \mathrm{m}^{2} /$ day; Karachi has $18.7 \mathrm{MJ} / \mathrm{m}^{2} /$ day; Multan has $18.36 \mathrm{MJ} / \mathrm{m}^{2} /$ day and; Peshawar receives 
the $17.0 \mathrm{MJ} / \mathrm{m}^{2} /$ day. The investigations were carried out by using the temperature ranges between minimum and maximum in that area and by considering the duration of irradiation. The estimate in this is compared with the National renewable energy laboratory (NREL) of USA and shows that batter average capacity of $5.5 \mathrm{kWh} / \mathrm{m}^{2} /$ day to $7.5 \mathrm{kWh} / \mathrm{m}^{2} /$ day [39]. While, the National Renewable energy laboratory of US indicates the average solar power from $5 \mathrm{kWh} / \mathrm{m}^{2} /$ day to $7 \mathrm{kWh} / \mathrm{m}^{2} /$ day [40]. Some cities in the province of Baluchistan and Sindh such as Larkana, Quetta receives the $5.5 \mathrm{kWh} / \mathrm{m}^{2} /$ day [41-43].

Power generation from the PV system is dependent on the environmental conditions due to the variations in surface temperatures across different parts of Pakistan. During summer months, consistent higher temperatures reduce the power generation capacity of the PV system, ultimately damaging the performance of PV panels and in winter temperature fall to a low level where PV panels perform under nominal temperatures [45]. To address the overheating issue, the temperature regulatory system is required with high reliability and fast real-time features and improving the durability of the PV system to its rated duty cycle [46]. PV system is becoming an important renewable energy source for power generation in Pakistan. Pakistan is situated in the region where some areas receive the higher solar irradiations in the summer months, it allows harnessing the large amount of solar energy [47], despite the fact the PV systems are not completely rolled out because of the recent crises of overheating of the PV panels and significant financial loss to consumers [48]. Thus, it is required to investigate the higher potential smart cities of Pakistan. Pakistan council of appropriate of technology and Pakistan national institute of silicon technology established the Pakistan council of renewable technologies in 2001. But this council did not investigate in great detail the suitable areas for installations of solar farms and it is questionable to see any working mega solar project for a drive towards smart cities [49]. The installations of solar energy at residential sectors and in an appropriate region with smart national grid connection would provide relief from severe load shedding.

This paper investigates the influence of hot arid climate temperatures on the PV panel performance for the investigation of the developing smart cities in Pakistan to avoid overheating and strategies to reduce the hot-arid climate impact on the energy efficiency of the PV panels by utilising validated MATLAB modelling approach for predictions. This paper contributes to investigate the suitable solar sites where the performance of PV system is analysed which influences the long-term durability of the solar power plants in Pakistan. This paper also contributes to quantitatively compare the performance of PV systems across the country and strategies in maintaining the reliability of PV systems and avoiding overheating of PV systems by introducing cooling strategies.

\section{Methodology}

A PV monocrystalline system is designed and modelled with the nominal power generation capacity of 295W and nominal power point output voltage 31.5 VDC for the residential sector in several areas of Pakistan. A schematic diagram of the model is shown in Fig.2 and the system is validated by analysing the simulation results in MATLAB and Simulink. The output power is calculated at different temperatures across several areas of Pakistan such as North-East, North-West, SouthEast and West side of Pakistan. The power generation from the PV system is predicted for winter and summer months.

The sunlight incident onto the monocrystalline PV cells can be absorbed or reflected or pass through the cells. The absorbed light by the cells generates electrical power also known as solar power [50,51]. PV cells achieve better efficiency when operated under nominal temperatures and it is important to examine the hot arid climate changes in several areas of Pakistan before considering 
the installation of the PV system [52]. For every degree rise temperature above $25^{\circ} \mathrm{C}$, an efficiency of the PV panels could be reduced to $0.25 \%$ for amorphous cells and $0.4-0.5 \%$ for crystalline cells [53]. During summer months, most areas of Pakistan reach $45^{\circ} \mathrm{C}$ that reduces the efficiency of the panels. An increase of cumulative surface temperatures causing over $60^{\circ} \mathrm{C}$ reduces the voltage generation by the PV system that impacts the overall power generation and minimises efficiency.

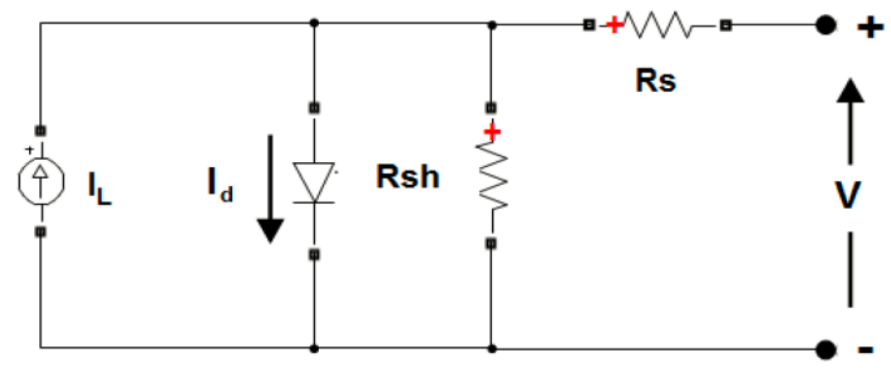

Fig. 2. Illustrates the schematic model of the typical monocrystalline PV cell. The measurements are used to examine the output at different temperatures

The power supplied by the PV modules is dependent on the internal resistance $\mathrm{R}$, external irradiance and incident temperatures. The temperature and irradiance directly affect the power generation from the PV system [54]. The nominal parameters of the implemented PV system are detailed in Table 1. The relation of the solar photovoltaic current to the temperature is described by Eq. (1) [55].

$\mathrm{I}_{\mathrm{Ph}}=\left(\mathrm{I}_{\mathrm{scn}}+\mathrm{K}_{1} \Delta \mathrm{T}\right) \frac{\mathrm{s}}{\mathrm{s}_{\mathrm{n}}}$

where $\mathrm{I}_{\mathrm{scn}}$ is the current generation at the suitable conditions i.e $25^{\circ} \mathrm{C}$ and $1000 \mathrm{~W} / \mathrm{m}^{2} . \Delta \mathrm{T}$ is the difference between the actual temperature and nominal temperature received by the monocrystalline PV module. $\mathrm{I}_{\mathrm{Ph}}$ is the photo voltaic current. $\mathrm{S}$ is the actual irradiation on the monocrystalline PV module and $S_{n}$ is the nominal irradiance [56].

The temperature effects on the diode saturation current $\mathrm{I}_{0}$ can be described as Eq. (2).

$I_{o}=I_{o n}\left(\frac{T}{T_{n}}\right)^{3} e^{\left[\frac{q_{G} E_{G o}}{N_{s} a k}\left(\frac{1}{T_{n}}-\frac{1}{T}\right)\right]}$

where $\mathrm{I}_{\mathrm{on}}$ the saturation is current, $\mathrm{E}_{\mathrm{Go}}$ is the bandgap semiconductor energy, $\mathrm{N}_{\mathrm{s}}$ is the total number of solar cells which are linked with series in the parallel as shown in Eq. (3) [57].

$\mathrm{I}_{\mathrm{on}}=\frac{\mathrm{I}_{\mathrm{scn}}+\mathrm{K}_{\mathrm{I}} \Delta \mathrm{T}}{\mathrm{e}^{\left(\left(\mathrm{V}_{\mathrm{ocn}}+\mathrm{K}_{\mathrm{V}} \Delta \mathrm{T}\right) / \mathrm{V}_{\mathrm{T}}\right)}}$

where $\mathrm{I}_{\text {on }}$ is the nominal saturation current that is improved by including the $\mathrm{K}_{\mathrm{I}}$ and $\mathrm{K}_{\mathrm{V}}$ coefficients. Where $\mathrm{K}_{\mathrm{I}}$ and $\mathrm{K}_{\mathrm{v}}$ are the current and voltage coefficients. This modification is used to determine the voltage at the several ranges of temperatures. The $\mathrm{I}_{\mathrm{o}}$ saturation current is dependent on the temperature. Efficiency of power generation depends on the temperature of the (PV) panel. Lower or nominal surface temperatures and higher irradiance enhances the efficiency to generate maximum power from the PV panel using Eq. (4). In the morning/evening during winter months, the solar irradiation reduces but the average surface temperatures are suitable that tends to generate the power at its achievable efficiency. 
$\mathrm{P}_{\mathrm{m}}=\mathrm{I}_{\mathrm{m}} \mathrm{V}_{\mathrm{m}}=\mathrm{I}_{\mathrm{SC}} \mathrm{V}_{\mathrm{oc}}$

where $\mathrm{V}_{\mathrm{OC}}$ is open circuit voltage and $\mathrm{I}_{\mathrm{SC}}$ is the short circuit current. $\mathrm{P}_{\mathrm{m}}$ is the maximum power generated by the PV panel at the weather temperature. A decrease in voltage, short circuit current and so efficiency can be calculated when increasing the surface temperature using Eq. (5) [58]

$\eta_{c}=\eta_{T r e f}\left[1-\beta_{\text {ref }}\left(T_{c}-T_{\text {ref }}\right)\right]$

where $\eta_{c}$ is correlation efficiency of the PV panel, $T_{\text {ref }}$ is the reference temperature, $\eta_{\text {Tref }}$ is the panel electrical efficiency at the applied temperature and irradiance where the maximum power is generated, $\beta_{\text {ref }}$ is the temperature coefficient calculated using Eq. (6) [59].

$\beta_{\text {ref }}=\frac{1}{\mathrm{~T}_{\mathrm{o}}-\mathrm{T}_{\mathrm{ref}}}$

where $\mathrm{T}_{\mathrm{o}}$ is the maximum temperature at which monocrystalline PV module efficiency shown in Table 1 . The relative efficiency is calculated by comparing the reference temperature of 25 o $C$ with the other temperatures. It shows the temperature effect on efficiency of the PV panel.

\section{Table 1}

Nominal parameters of the implemented PV system (relative efficiency calculations using $25^{\circ} \mathrm{C}$ and $1000 \mathrm{~W} / \mathrm{m}^{2}$ as a reference point)

\begin{tabular}{ll}
\hline Parameters & Values \\
\hline Nominal Peak Power Output & $295 \mathrm{~W}$ \\
Maximum power point voltage & $31.5 \mathrm{VDC}$ \\
Maximum output current (A) & $5.71 \mathrm{~A}$ \\
Open circuit voltage & $40.0 \mathrm{VDC}$ \\
Short circuit current & $10.10 \mathrm{~A}$ \\
Maximum power point current & $9.45 \mathrm{~A}$ \\
Panel efficiency & $17.59 \%$ \\
\hline
\end{tabular}

\subsection{Weather temperatures across Pakistan}

Temperature is one of the major properties which conclude the climate of any area. Any change in temperature results in the change of climate of the region affecting the power generation from the PV system [34]. Most of the areas in Pakistan experienced higher weather temperatures influencing higher surface temperatures elevating above $45^{\circ} \mathrm{C}$ during summer months. During winter months the temperature goes to $-15^{\circ} \mathrm{C}$ in the northern area [60]. Fig. 3(a) shows the temperature across several areas of Sindh (Southern Pakistan) where Thar and Larkana are suffering through the highest temperature during the summer months. These areas are also in the high temperature ranges during winter months. Fig. 3(b) illustrates the surface temperature in Gilgit Baltistan and Azad Kashmir (North East Pakistan) where the winter temperature goes to very low $-15^{\circ} \mathrm{C}$ and the summer temperature remains between $30^{\circ} \mathrm{C}$ and $40{ }^{\circ} \mathrm{C}$. The temperature in the area of Khyberpakhtoonkhaw (North West Pakistan), as shown in Fig. 3(c), varies across several areas. Fig. 3(d) demonstrates the temperature in the province of Baluchistan (West Pakistan) in which during winter months some areas are predicted to be at lower temperature of $-15^{\circ} \mathrm{C}$. Temperature values 
in Punjab (East Pakistan) are shown in Fig. 3(e) where the summer temperature remains between $40^{\circ} \mathrm{C}$ and $50^{\circ} \mathrm{C}$. The average temperatures in several areas of Pakistan are listed in Table 2 distributed across summer, spring and winter months. As the performance of the PV module is linked with temperature, hence the average temperature influence on PV panels in different areas of Pakistan need to analysed [61].

Southern Pakistan

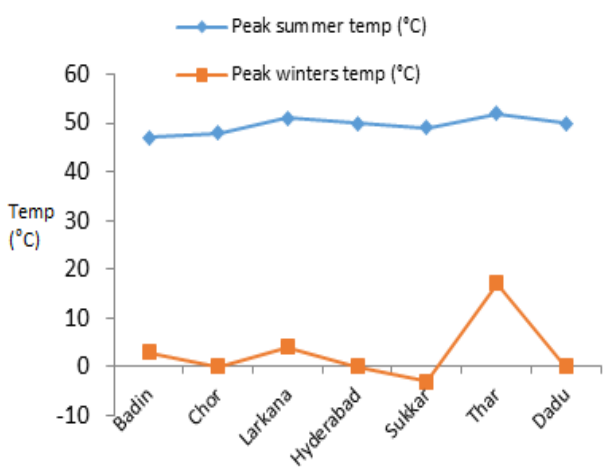

(a)

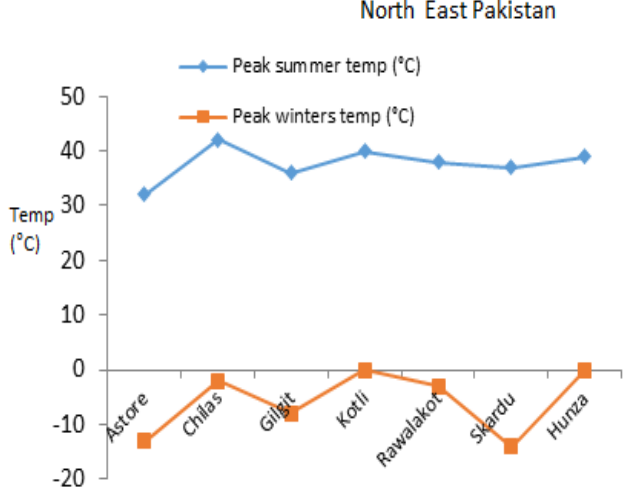

(b)

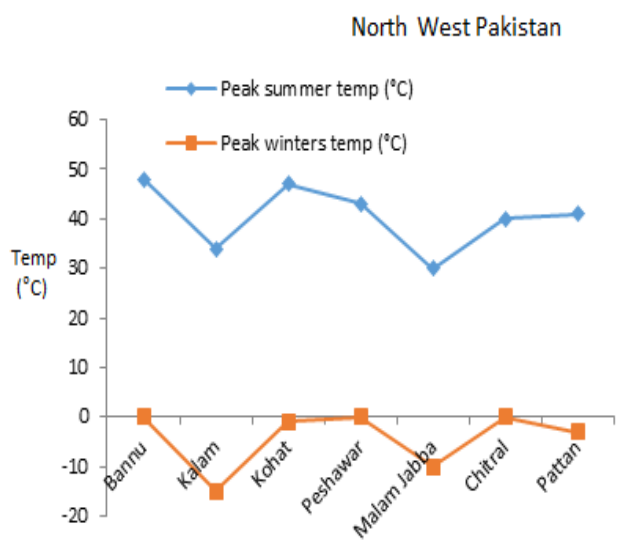

(c)

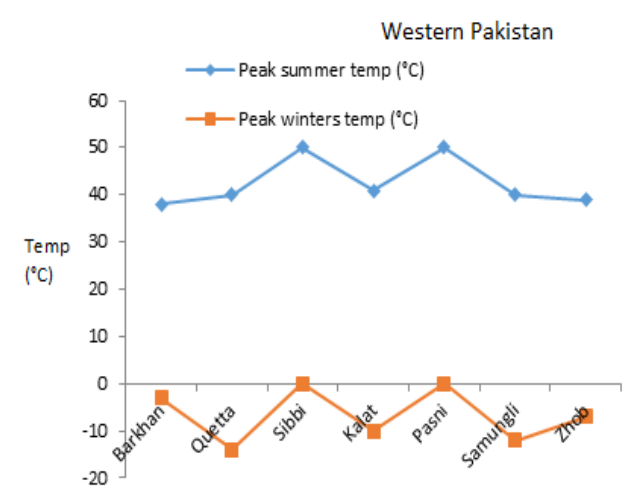

(d)

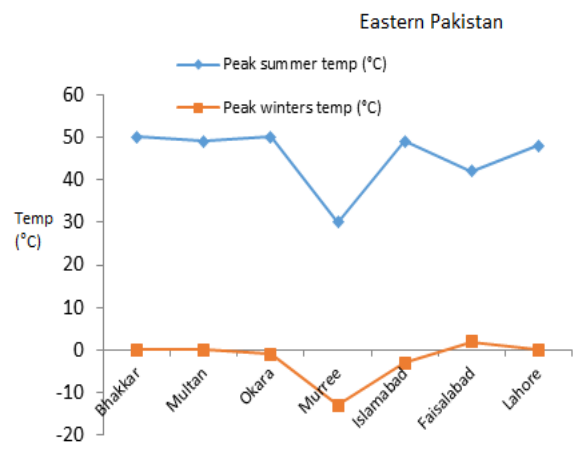

(e)

Fig. 3. Peak summer and winter temperature measurements of (a) Southern, (b) North East, (c) North West, (d) West, \& (e) Eastern regions of Pakistan 
Table 2

Average Ambient temperatures in most of the areas of Pakistan [41]

\begin{tabular}{lllll}
\hline Parameters & $\begin{array}{l}\text { North average } \\
\text { ambient } \\
\text { temperature }\end{array}$ & $\begin{array}{l}\text { South average } \\
\text { ambient } \\
\text { temperature }\end{array}$ & $\begin{array}{l}\text { East average } \\
\text { ambient } \\
\text { temperature }\end{array}$ & $\begin{array}{l}\text { West average } \\
\text { ambient } \\
\text { temperature }\end{array}$ \\
\hline Summer & $45^{\circ} \mathrm{C}$ & $55^{\circ} \mathrm{C}$ & $50^{\circ} \mathrm{C}$ & $49^{\circ} \mathrm{C}$ \\
Winter & $-15^{\circ} \mathrm{C}$ & $-3^{\circ} \mathrm{C}$ & $-15^{\circ} \mathrm{C}$ & $-13^{\circ} \mathrm{C}$ \\
\hline
\end{tabular}

\section{Results and discussion}

The parametric data plotted to determine the correlation between power (W), current (I) and voltage (V) with cumulative hot-surface extreme temperatures range of $-40^{\circ} \mathrm{C}$ and $90^{\circ} \mathrm{C}$. Higher temperatures are due to the overheating of the PV panel, since the surface absorbs and continuously add solar irradiations unlike oven where controlled temperatures are possible. Fig. 4 (a) illustrates the voltage reduction by the increase in surface temperatures. It shows the output voltage from the PV system in the range of $1000 \mathrm{~W} / \mathrm{m}^{2}$. The desired voltage is $31.5 \mathrm{VDC}$ and the achieved voltage is reduced to $25.2 \mathrm{VDC}$ when increasing the temperature but at the range between $0^{\circ} \mathrm{C}$ and $50^{\circ} \mathrm{C}$, voltage was predicted to be very close to the nominal voltage. As the weather temperatures are dynamic, it was necessary to predict the PV system at the lower-temperature areas or by using cooling techniques which then increases the energy cost. However, it will increase the output efficiency of the power generation when operating the PV system under nominal weather conditions. Fig. 4(b) shows an influence of increasing the surface temperature on the output power of the modelled PV system. For every degree rise in temperature above $25^{\circ} \mathrm{C}$, a decrease in the efficiency of the PV panel $0.25 \%$ is predicted for amorphous cells and $0.4-0.5 \%$ for crystalline cells. The output energy generated is reduced due to the increase of surface temperature effects on the PV panels. Fig.4 (c) shows the temperatures effects on the output current from the PV system, illustrating the output current for several temperature ranges.

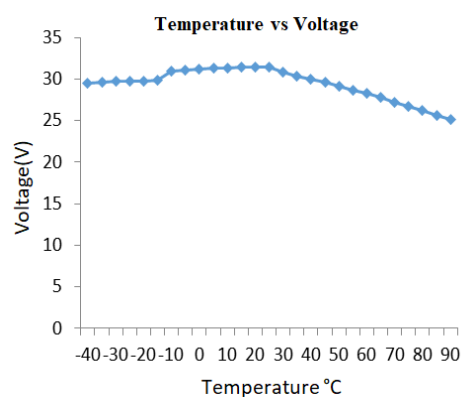

(a)

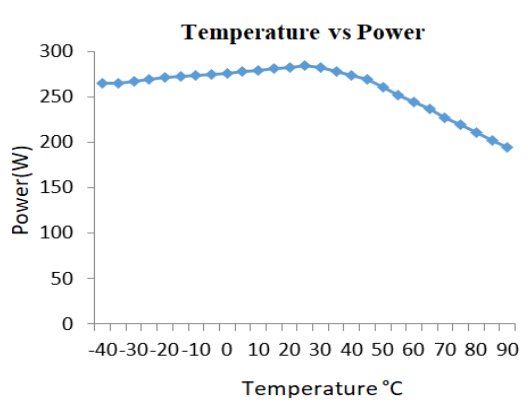

(b)

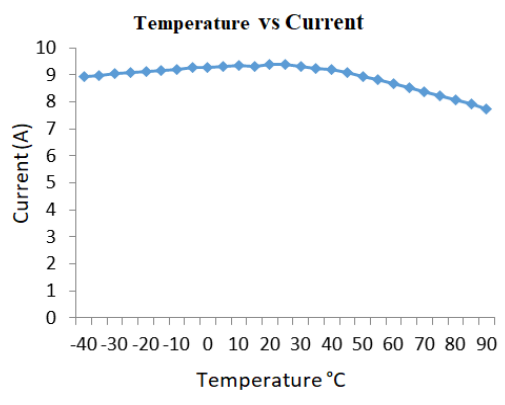

(c)

Fig. 4. (a) Illustration of the temperature effects on the voltage. (b) Temperature vs output electrical power from the modelled PV system. (c) Output current variations at different temperature

The simulation is carried out validating the temperature effects on the PV system where the voltage $(\mathrm{V})$, current $(\mathrm{A})$ and Power $(\mathrm{W})$ are analysed and the simulation of the system is shown in Fig. 5. 


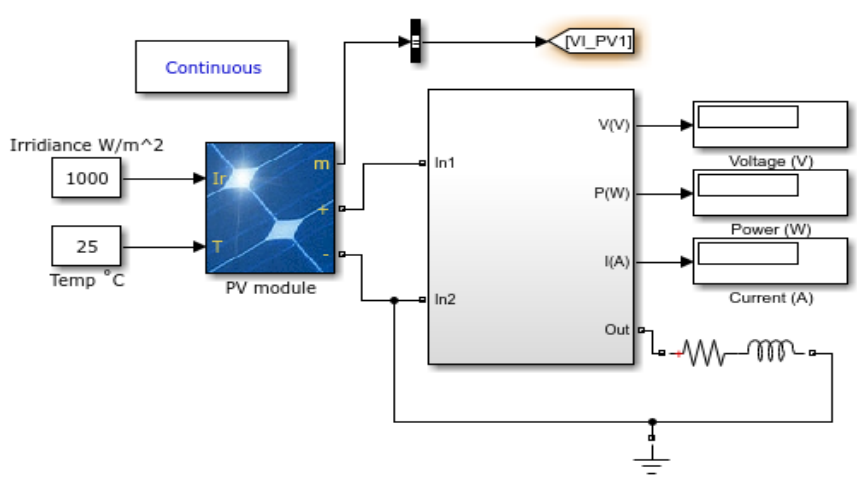

Fig. 5. The model of the simulated monocrystalline PV module tested at dynamic surface temperatures

\subsection{PV Panel Performance in East Pakistan}

Investigations are performed to investigate the conversion of the solar irradiations into electrical energy and to achieve the desired output power at different temperatures, PV orientation and irradiation levels. In order to investigate the power flow from the PV system, current-voltage linkage is analysed. PV modules can be designed in parallel and series to achieve the required output power [39]. The current-voltage and efficiency are investigated in Eastern Pakistan to examine the temperature power flow, a similar approach is used in [48]. In this study, degree day (24 hours) temperature analysis is carried out for peak summer and winter months. The performance of PV array is changing according to the forecast horizon. The day-light hours in summer months are more considerable for the PV system due to severe changes in temperature, air speed and humidity. Therefore, different weather forecast focused to predict the power generation efficiency from the modelled PV system. This analysis can be used for energy management of integrated buildings across Pakistan. The installations cost of the PV system [30] can be minimised with the help of temperature analysis with accuracy. Investigations are carried out in Eastern Pakistan to examine power generation efficiency from PV system. The output power, short circuit current and voltage are recorded against temperatures. It is observed during the cold season, the energy efficiency of the PV system modelled has remained closer to the achievable nominal values. By increasing surface temperatures, a reduction in voltage and current are observed causing a decrease in maximum output power as detailed in Table 3.

Table 3

The output power losses compared to the nominal power output from the modelled PV system in the Eastern region of Pakistan.

\begin{tabular}{ll}
\hline Days & Average Power loss (W) \\
\hline $11^{\text {th }}$ January & 28 \\
$30^{\text {th }}$ June & 56 \\
\hline
\end{tabular}

Figure 6 (a) shows the electrical output parameters of the PV panels for a peak cold day in the month of January. The results are performed in the eastern Pakistan where the capital of eastern Pakistan 'Lahore' is taken for investigations. The recorded data voltage (V), power (W) and Current (I) are used to plot and investigate the variations in these parameters. It is noticed that the Power output is decreasing with the increase of temperature. The voltage is also reducing by increasing in temperature. Output current $\mathrm{I}_{\mathrm{Sc}}$ affected through marginal changes. The power generation efficiency 
during the peak summer day in the month of June is lower than the peak cold day. Higher temperatures are recorded during summer months which are decreasing the energy efficiency of the PV panels. The Fig.6 (b) shows the temperature on the power generation efficiency of the PV system simulated during the summer months for the eastern region of Pakistan.

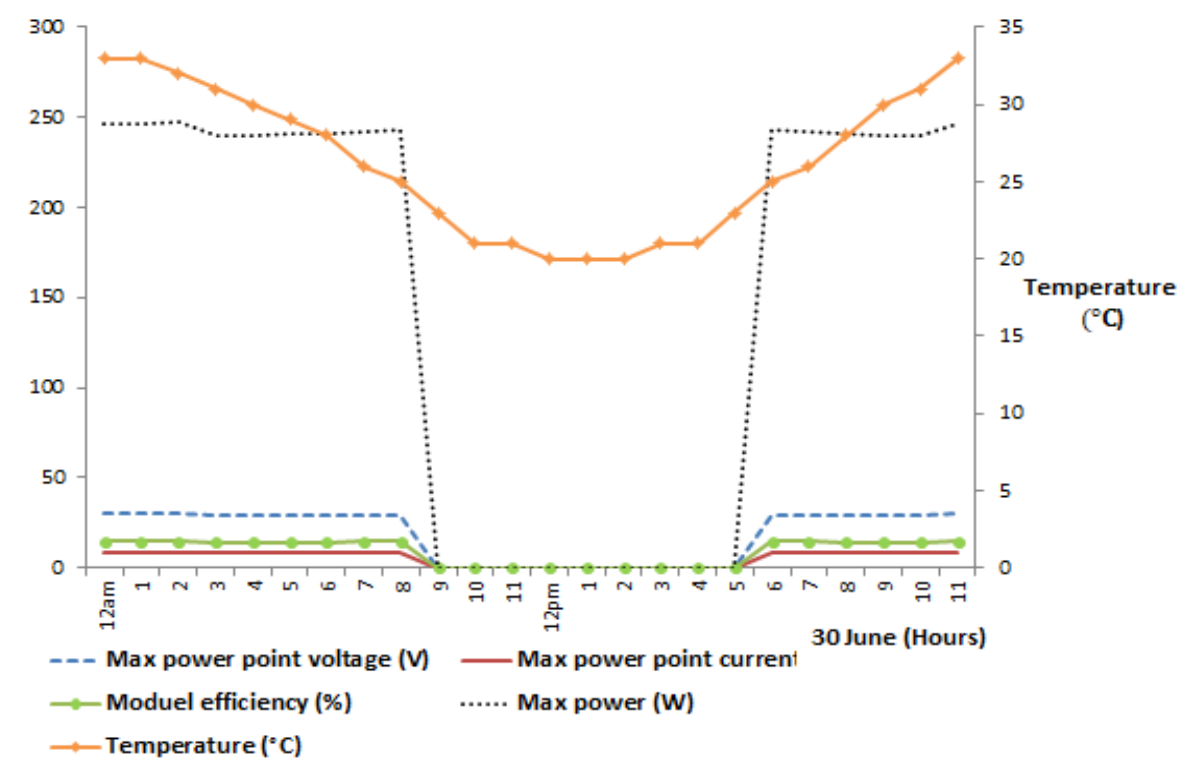

(a)

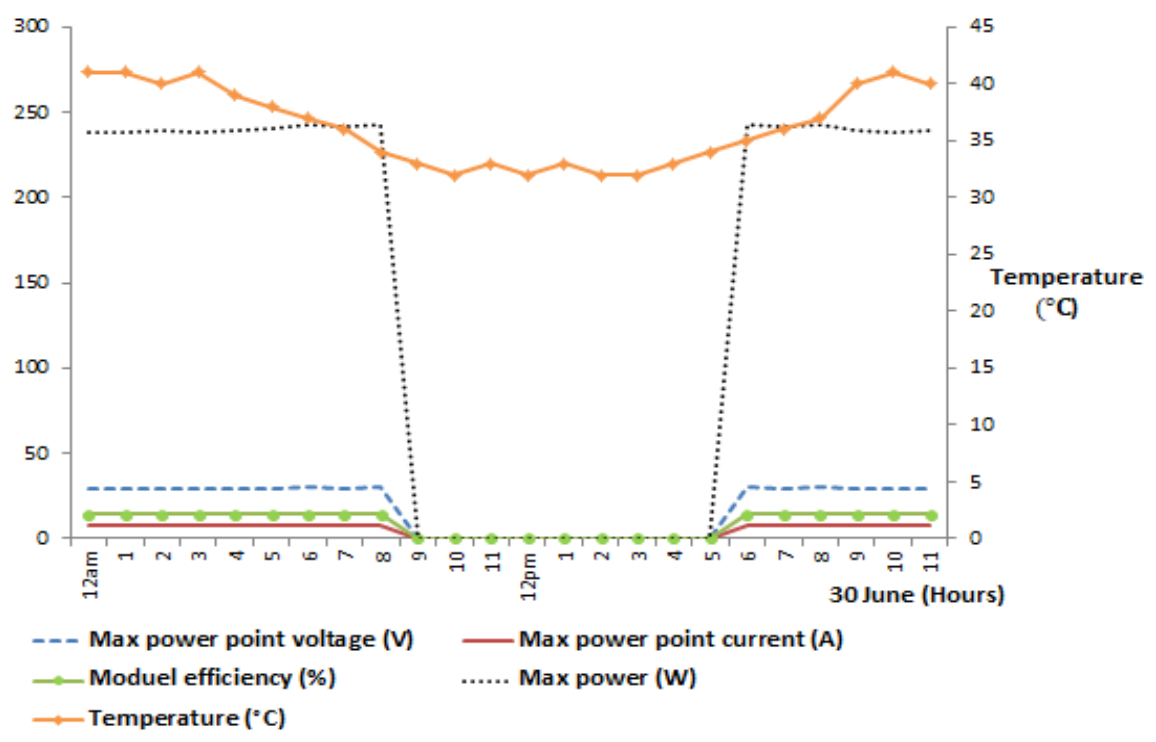

(b)

Fig. 6. Temperature effects on the performance of simulated PV panel in the eastern city of Lahore (a) for a peak winter day and (b) peak summer day.

\subsection{PV Panel Performance in West Pakistan}

The performance of the PV system with real time peak day temperatures were analysed for winter and summer months in the Western region of Pakistan, a capital city Quetta is chosen for investigating the PV system performance, current/voltage and efficiency against the surface temperature of the PV panel as shown in Fig. 7. It shows PV panel output performance is closer to 
the nominal values with an achievable maximum voltage of 29.50 VDC, short circuit current of $8.1 \mathrm{~A}$. Here the short circuit voltage and current are considered to examine the voltage/power drops at different temperatures as detailed in Table 4. Average power losses of $24 \mathrm{~W}$ were recorded for the coldest day ( $11^{\text {th }}$ Jan) and $52 \mathrm{~W}$ for the hottest day ( $30^{\text {th }}$ Jun).

\section{Table 4}

The output energy losses from the modelled PV system in western region of Pakistan

\begin{tabular}{ll}
\hline Days & Average power losses (W) \\
\hline $11^{\text {th }}$ January & 24 \\
$30^{\text {th }}$ June & 52 \\
\hline
\end{tabular}

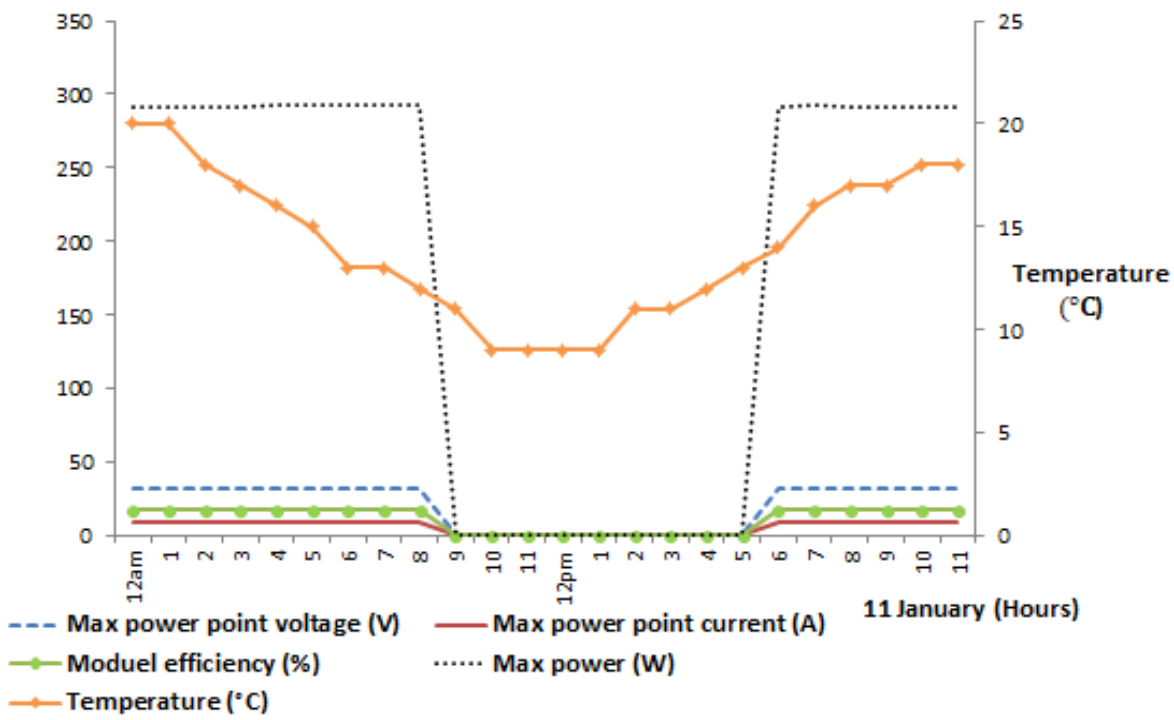

(a)

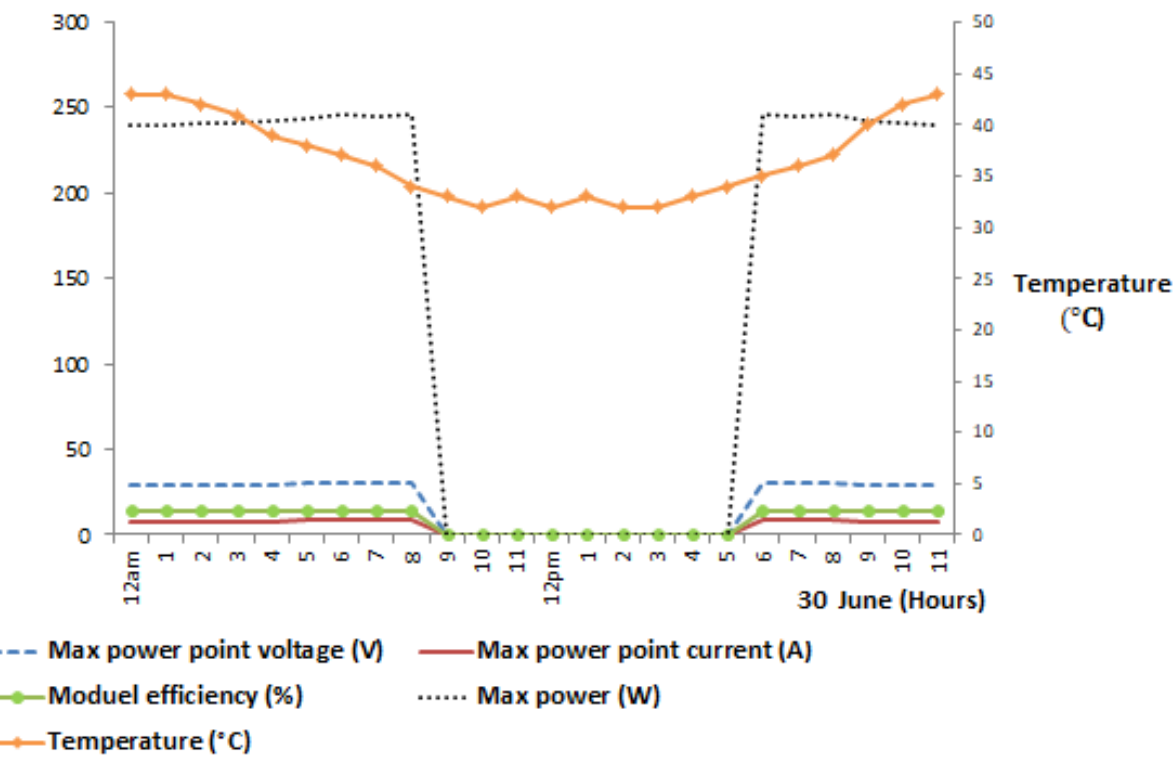

(b)

Fig. 7. Temperature influences on the reduction of the performance of simulated PV system in Quetta, West of Pakistan (a) for a peak winter day (b) Peak summer day. 


\subsection{PV panel performance in South Pakistan}

An off-grid PV system in the southern area of Pakistan show a reduction output power, detailed in Table 5. During the investigations, the data has been collected for the 24 hours, to investigate the weather effects on the PV system to compare the efficiency of the system during winter and summer months. The maximum temperature observed in the southern region (Thar) during the winter season is $29^{\circ} \mathrm{C}$ and the temperature remains between (30-55) ${ }^{\circ} \mathrm{C}$ during summer months. The results showed that this area required cooling systems of PV panels in both summer and winter seasons and the PV array performance could be severely reduced because of the temperature remains higher during both seasons. The voltage is dropped to 29.31 VDC compared to the nominal voltage of 31.5 VDC. The average power losses, compared to the nominal power output, was noticed $32 \mathrm{~W}$ and $57 \mathrm{~W}$ for the peak cold day and peak hot day, respectively, between 5am and 9pm. Figure 8 shows the power flow analysis on the Thar, Southern region of Pakistan.

\section{Table 5}

The output Power losses compared to the nominal power output from the modelled PV system in the Southern region of Pakistan

\begin{tabular}{ll}
\hline Days & Average Power losses (W) \\
\hline $11^{\text {th }}$ January & 32 \\
$30^{\text {th }}$ June & 57 \\
\hline
\end{tabular}

\subsection{PV panel performance in North Pakistan}

PV panel works efficient at a certain temperature and the best temperature for the PV panel is $25^{\circ} \mathrm{C}$, average power losses are detailed in Table 6 . There are needs to design new ways to improve the efficiency of the PV system during the non-optimal temperatures such as cooling techniques. In this section, investigations are performed to examine the solar power generation at North Pakistan Gilgit area. This is the mountainous area where the temperature remains between $(-5 \text { to } 33)^{\circ} \mathrm{C}$ throughout a year. This area is more suitable to install the PV modules because of efficient temperature. Fig. 9 illustrates the temperature effects on the power generation at Gilgit, North Pakistan. The PV power generating efficiency and voltage are improved as being closer to the nominal values. This is the best area that shows the improved results for the PV panel throughout a year.

\section{Table 6}

The output energy losses from the modelled PV system in the northern region of Pakistan

\begin{tabular}{ll}
\hline Days & Average energy losses $(\mathbf{W})$ \\
\hline $11^{\text {th }}$ January & 17 \\
$30^{\text {th }}$ June & 48 \\
\hline
\end{tabular}




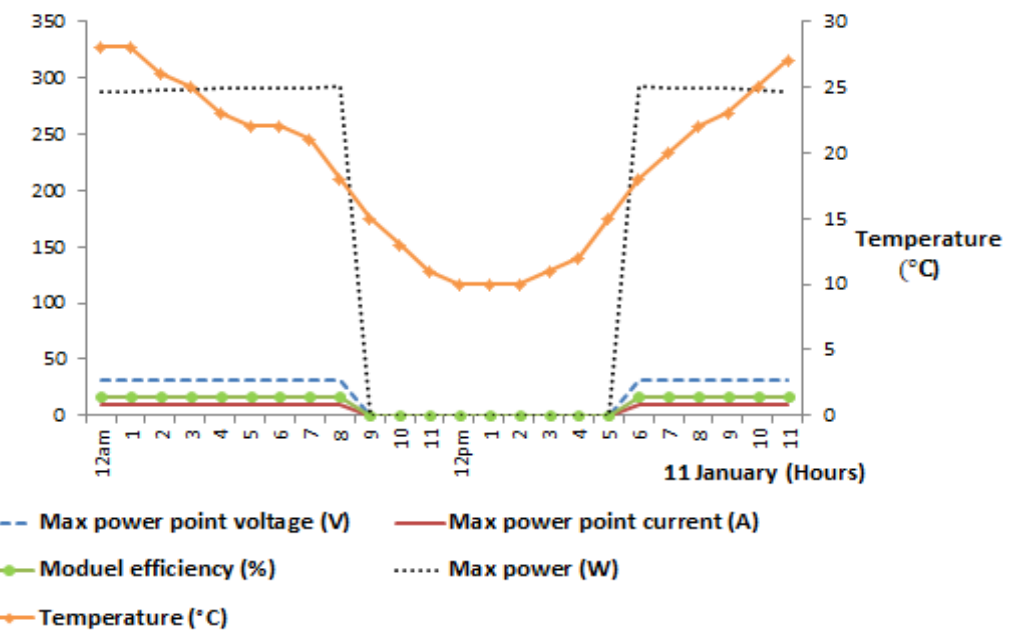

(a)

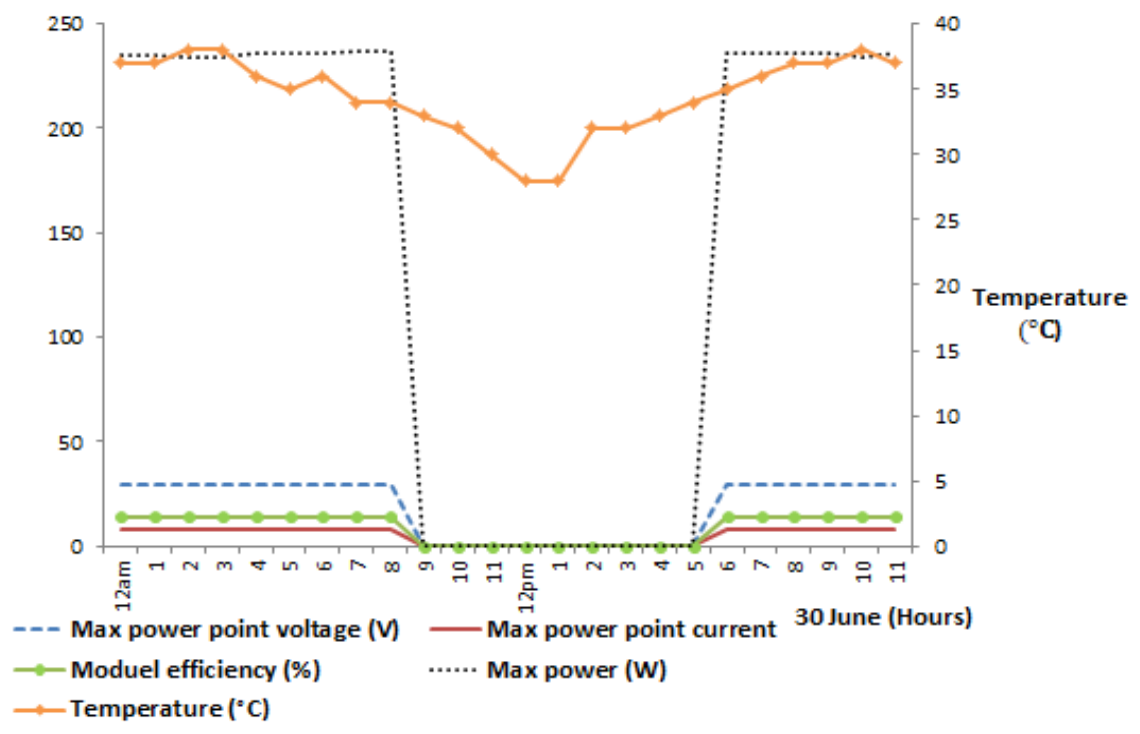

(b)

Fig. 8. Temperature influences on the reduction of the performance of simulated PV system in Thar, South of Pakistan (a) for a peak winter day (b) Peak summer day. 


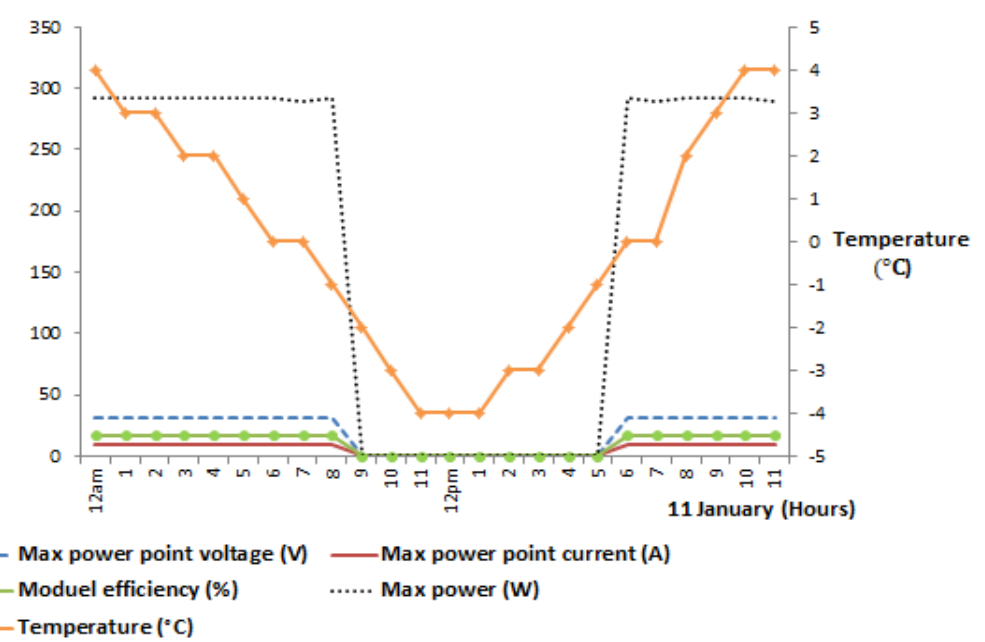

(a)

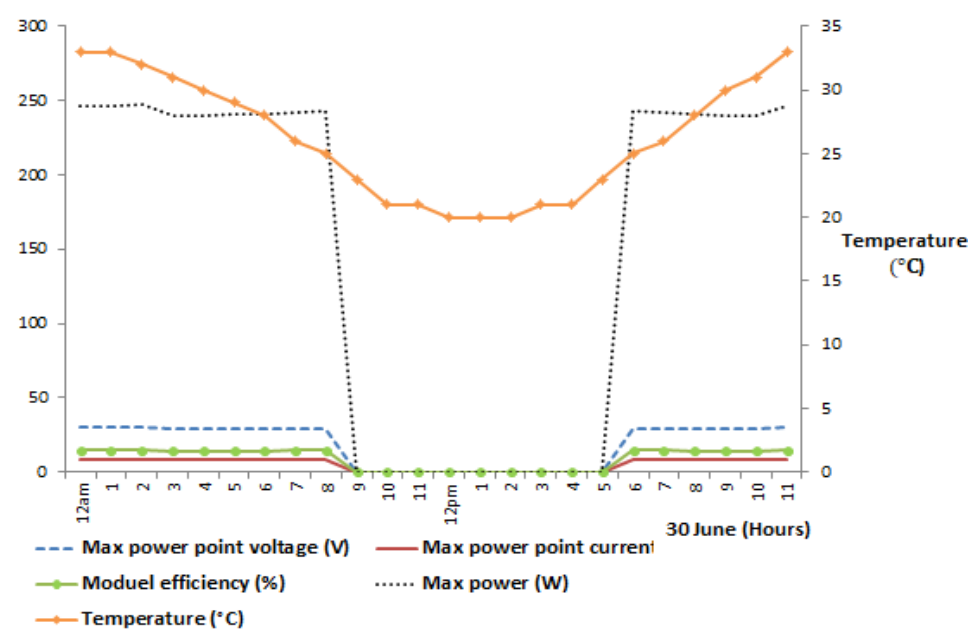

(b)

Fig. 9. (a) Power generation from the PV system in Gilgit, North Pakistan, during winter season shows PV system generates the power/voltage efficiently and better than the rest of the regions of Pakistan. (b) Power analysis on the hottest day of $30^{\text {th }}$ June

\subsection{Comparative analysis of PV panel for the different regions of Pakistan}

The northern areas of Pakistan, as shown in Fig. 10, have the lower power reduction at all weather conditions. In other parts, during the summer losses are increasing with a temperature rise that areas are not perfect for installations of PV system. The effect can be minimized by implementing cooling techniques that reduce the temperature effects during summer months. During this day, all of the areas are showing better performance for the power generation from the PV panel. 


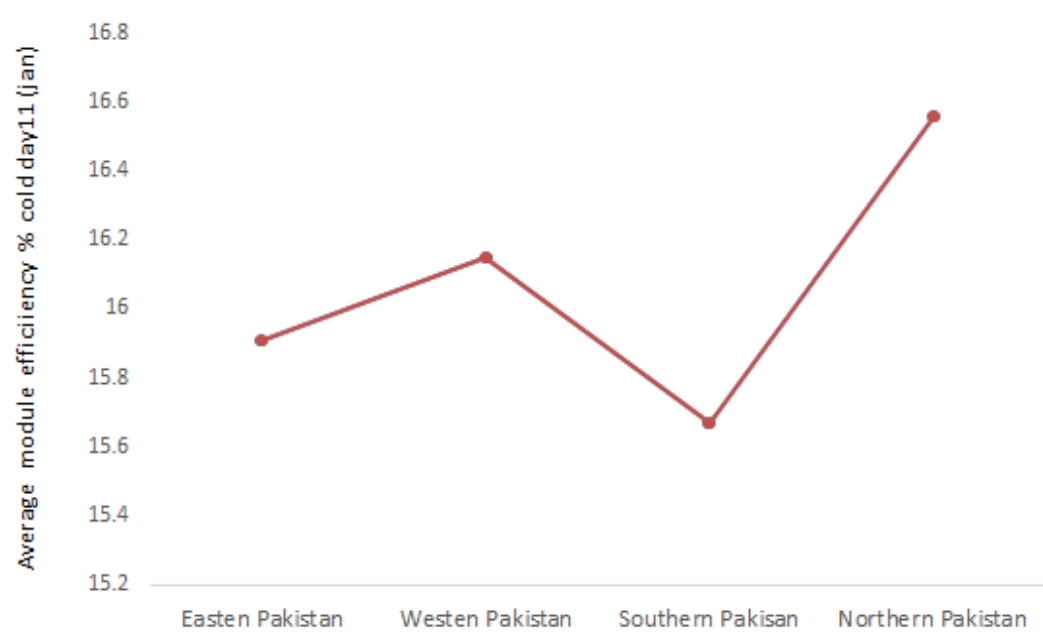

(a)

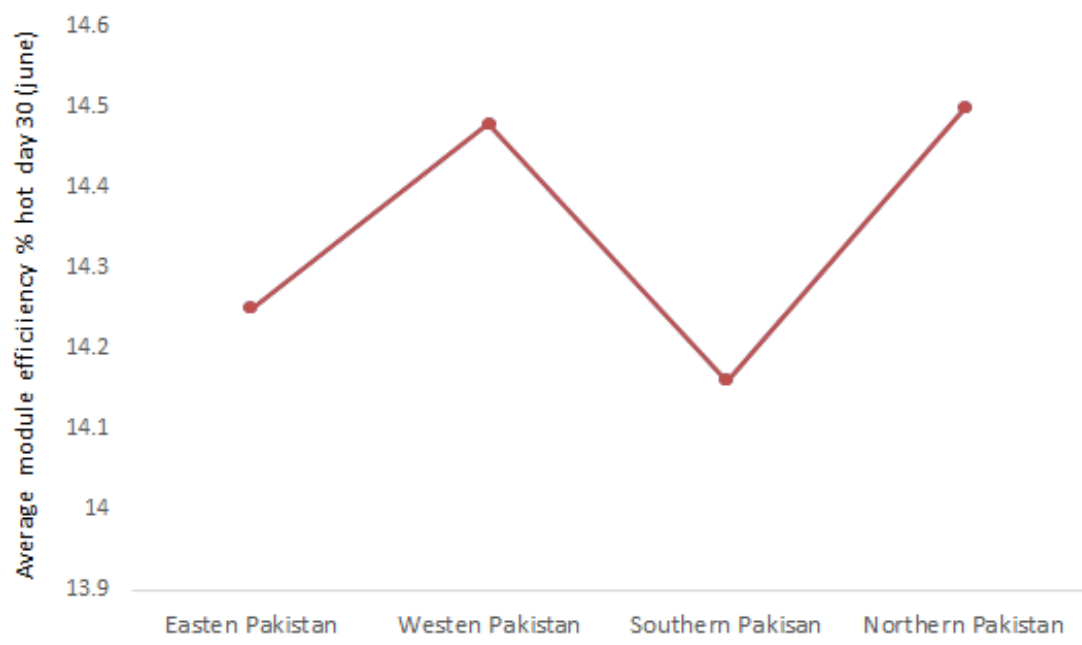

(b)

Fig. 10. Comparative energy efficiency analysis on the (a) peak day (11 $1^{\text {th }}$ January) of the winter months (b) peak day of the summer months ( $30^{\text {th }}$ June)

\section{Cooling strategies for the PV panel overheating}

Higher temperature reduces the efficiency of the PV panel to generate nominal electrical energy. Hence it is necessary to apply the cooling techniques to maximise the energy generation from the PV system. To implement the cooling techniques, progressive technologies are required to reduce the overheating effects on the PV system. There are two types of cooling techniques can be used such as passive cooling and active cooling. The active cooling technique is of the use of water or nanofluid cooling methods and the passive system uses thermoelectric Peltier modules [62] to remove the heat from the PV system.

\subsection{Active cooling}

An active cooling method consists of water or nanofluid cooling methods or air cooling. It is considered of using the electrical energy continuously because a water pump or a fan is required for implementing fluid/water circulation. This improves the energy generation capacity of the PV system but the energy consumption by fan/pump needs to be considered. This method can be efficiently 
applied for the concentrated solar cells that use less cooling fluid and a reduced amount of energy is required to run the system. Two polycrystalline cells are compared to determine the energy extraction by applying these methods. An aluminium casing is used on the back side of the cooling cell to perform as a flow canal. Water cooling method performs batter then the other methods. This technique can be applied at both sides of the PV system and also assist in cleansing of the PV panel. By applying water, the temperature was limited to $30{ }^{\circ} \mathrm{C}$ in the summer seasons that has increased the energy output to $20 \%$ that means the overall efficiency is improved by $4.5 \%$ and a temperature is decreased by $8{ }^{\circ} \mathrm{C}$. While by implementing the fan system, an improvement to overall system efficiency was noticed and temperature of the PV panel is reduced by $5^{\circ} \mathrm{C}$.

\subsection{Passive cooling}

A Passive cooling is predominantly a thermoelectric Peltier conductive cooling method that cool down the hot surface of the PV system. The transfer of heat from the PV panel is conductive in nature. Two PV polycrystalline cells are tested in different conditions. One PV cells consists of aluminium sheet with thermal grease used as a heat sink and the other without any sheets. Irradiation is changed from $1000 \mathrm{~W} / \mathrm{m}^{2}$. An improved efficiency is achieved by the usage of heat sink by passive thermoelectric cooling method. It means that the passive cooling has a major impact on the energy extraction from the PV system [63-65]. It is noticed that 0.085 length-depth ratio heats up the PV panel by $6{ }^{\circ} \mathrm{C}$ by comparing it on a regular environment. The implementation of passive cooling technique shows the reverse effects on the PV panel heating. Phase change material is a special type for the conductive cooling where heat absorption could be advantageous. It maintains the required temperature for the PV panel to increase its efficiency. In this process heat is removed conductively and no additional work is needed to dissipate the heat. By selecting the correct material for the conduction process, a reference temperature for the PV panel can be obtained. The efficiency is improved by $3.5 \%$ compared to the actual temperature applied at the PV panel without any conduction. The decrease in temperature is observed from $55^{\circ} \mathrm{C}$ to $35^{\circ} \mathrm{C}$.

Another method is a heat pipe cooling method that is applied by the combination of convection cooling system along with phase change cooling. It removes the heat by going through evaporation and expansion on one side cooling system and release the heat by condensation on the other side of the cooling system. It completes the phase by continuous movement of the liquid by capillary pipes and evaporates. The stable output energy is noticed by using the cooling of heat pipes with water. The energy efficiency is improved by $8.4 \%$. Another cooling technique for reducing the temperature of PV panel is the thermoelectric cooling method that is used to transfer heat in the specific direction. It produces cooling on one side of the junction and heating effects on the other side. The intensity of the heating and cooling material depends on the nominal output power. The higher output power creates more heat and vice versa. This method is useful for specific PV cells where these cells required maintaining cooling.

\section{Conclusions}

Substantial efforts in tackling the energy shortage are being applied with the rollout of Photovoltaic (PV) panels in all regions of Pakistan in reducing the carbon emissions with a drive towards the sustainable smart cities as a developing country. The main advantage of installing the PV system is to reduce load shedding in the residential sectors and to minimise overloading the National grid. This will reduce the gap between the energy supplies and consumed and will leave positive impact on the country economy. However, most of the urban areas in Pakistan stay hot and humid in the 
entire year. Consistent solar irradiation at higher temperatures is one of the major factors that affect the power generation performance of the monocrystalline PV modules. Since all the locations in Pakistan have different temperatures, so before installing the PV system temperature analysis needs to be carried out. The conclusive remarks from this study are:

i. A simulation is carried out to examine the thermal effects on the monocrystalline PV system. As part of the investigations; degree day (24 hours) analysis were performed for the four major areas of Pakistan where the cold and hot day's temperatures are taken for investigations.

ii. A decline in power generating efficiency by monocrystalline PV system due to the rise in surface temperature was investigated. It is found that during summer months, the southern and eastern regions of Pakistan affected the output power capacity of PV system.

iii. It is analysed that the areas in the North region of Pakistan such as Gilgit have an achievable better performance where the voltage/power generation efficiencies of the PV panel are closer to the nominal values than the other regions throughout the year and is a suitable region for the installations of monocrystalline PV modules. This area is found efficient because of suitable temperature ranges between $0-30^{\circ} \mathrm{C}$ throughout the year.

iv. During the summer months, the rest of Pakistan's temperature goes very high that decreases the power generation from the monocrystalline PV systems. But during the winters, the achievable efficiencies are considerably better throughout Pakistan.

\section{Acknowledgment}

Authors would like to thank the research facilities support provided by the TWI Centre for Automation of NDT, Solar Thermal Vacuum Engineering Research Group at London Centre for Renewable Energy Engineering and Research Enterprise \& Innovation Centre at London South Bank University. This research is self-funded and did not receive any specific grant from funding agencies in the public, commercial, or not-for-profit sectors.

\section{Data Availability}

In support of open access research, all supplementary data to this article is available and can be found online at:

- [dataset] Khan, A (2019). Analysing integrated renewable energy and smart-grid systems to improve voltage quality and harmonic distortion losses at electric-vehicle charging stations. PhD Thesis London South Bank University School of Engineering https://doi.org/10.18744/LSBU.003183

- [Preprint] Khan, Asif, and Saim Memon. "Performance Evaluation of Monocrystalline PV Module in Hot Arid Climate for Developing Smart Cities." (2019).

https://doi.org/ 10.20944/preprints201909.0080.v1

\begin{tabular}{|lll|}
\hline Nomenclature & & \\
$S$ & Actual irradiance & {$\left[\mathrm{W} / \mathrm{m}^{2}\right]$} \\
$R_{p}$ & Solar panel internal resistance & {$[\Omega]$} \\
$I_{s c n}$ & Solar current generation & {$[\mathrm{A}]$} \\
$T$ & Time & {$[\mathrm{s}]$} \\
$\Delta T$ & Change in temperature difference & {$\left[{ }^{\circ} \mathrm{C}\right]$} \\
$S_{n}$ & Nominal irradiance & {$\left[\mathrm{W} / \mathrm{m}^{2}\right]$} \\
$I_{p h}$ & Photovoltaic current & {$[\mathrm{A}]$} \\
$K_{1}$ & Temperature coefficient & {$\left[{ }^{\circ} \mathrm{C}\right]$} \\
$I_{O}$ & Saturation current dependent on temperature & {$[\mathrm{A}]$} \\
$\mathrm{I}_{\text {on }}$ & Nominal saturation current & {$[\mathrm{A}]$} \\
\hline
\end{tabular}




\begin{tabular}{|lll|}
\hline$T$ & Temperature & {$\left[{ }^{\circ} \mathrm{C}\right]$} \\
$V_{O S}$ & Open circuit voltage & {$[\mathrm{V}]$} \\
$\mathrm{P}_{\mathrm{m}}$ & Maximum power & {$[\mathrm{W}]$} \\
$\mathrm{I}_{\mathrm{SC}}$ & Short circuit current & {$[\mathrm{A}]$} \\
$\eta_{\mathrm{c}}$ & correlation efficiency & {$[\%]$} \\
$\eta_{\mathrm{Tref}}$ & panel electrical efficiency & {$[\%]$} \\
$\mathrm{T}_{\mathrm{ref}}$ & Reference temperature & {$\left[{ }^{\circ} \mathrm{C}\right]$} \\
$\beta_{\mathrm{ref}}$ & Temperature coefficient & {$\left[{ }^{\circ} \mathrm{C}\right]$} \\
$\mathrm{T}_{\mathrm{o}}$ & Temperature increment & {$\left[{ }^{\circ} \mathrm{C}\right]$} \\
$\mathrm{I}_{\mathrm{m}}$ & Maximum current & {$[\mathrm{A}]$} \\
$\mathrm{V}_{\mathrm{m}}$ & Maximum voltage & {$[\mathrm{V}]$} \\
Abbreviations & & \\
& & \\
$\mathrm{MWh}$ & Electricity generated in Mega-Watt Hour & \\
$\mathrm{VDC}$ & DC Voltage & \\
AK & Azad Kashmir & \\
$\mathrm{KP}$ & Khyberpakhtoonkhaw & \\
$\mathrm{PV}$ & Photo-voltaic & \\
\hline
\end{tabular}

\section{References}

[1] Parida, Bhubaneswari, S_ Iniyan, and Ranko Goic. "A review of solar photovoltaic technologies." Renewable and sustainable energy reviews 15, no. 3 (2011): 1625-1636. https://doi.org/10.1016/j.rser.2010.11.032

[2] Bounechba, Hadjer, Aissa Bouzid, Hamza Snani, and Abderrazak Lashab. "Real time simulation of MPPT algorithms for PV energy system." International Journal of Electrical Power \& Energy Systems 83 (2016): 67-78. https://doi.org/10.1016/j.ijepes.2016.03.041.

[3] Javid, Muhammad, and Abdul Qayyum. "Electricity consumption-GDP nexus in Pakistan: A structural time series analysis." Energy 64 (2014): 811-817. https://doi.org/10.1016/j.energy.2013.10.051

[4] Ahmad, Ali, Muhammad Asghar Saqib, Syed Abdul Rahman Kashif, Muhammad Yaqoob Javed, Abdul Hameed, and Muhammad Usman Khan. "Impact of wide-spread use of uninterruptible power supplies on Pakistan's power system." Energy Policy 98 (2016): 629-636. https://doi.org/10.1016/j.enpol.2016.09.039.

[5] Raza, Syed Ali, Muhammad Shahbaz, and Duc Khuong Nguyen. "Energy conservation policies, growth and trade performance: Evidence of feedback hypothesis in Pakistan." Energy Policy 80 (2015): 1-10. https://doi.org/10.1016/j.enpol.2015.01.011.

[6] Memon, S., T. Katsura, A. Radwan, S. Zhang, A. A. Serageldin, E. M. Abo-Zahhad, S. Sergey et al. "Modern eminence and concise critique of solar thermal energy and vacuum insulation technologies for sustainable low-carbon infrastructure." International Journal of Solar Thermal Vacuum Engineering 1, no. 1 (2020): 52-71. ISSN online (2716-6953).

https://doi.org/10.37934/stve.1.1.5271

[7] Ahmed, Mostafa, Ali Radwan, Ahmed Serageldin, Saim Memon, Takao Katsura, and Katsunori Nagano. "Thermal Analysis of a New Sliding Smart Window Integrated with Vacuum Insulation, Photovoltaic, and Phase Change Material." Sustainability 12, no. 19 (2020): 7846. https://doi.org/10.3390/su12197846

[8] Das, Indrajit, Kankar Bhattacharya, and Claudio Canizares. "Optimal incentive design for targeted penetration of renewable energy sources." IEEE Transactions on Sustainable Energy 5, no. 4 (2014): 1213-1225. https://doi.org/10.1109/TSTE.2014.2339172

[9] Sampaio, Priscila Gonçalves Vasconcelos, and Mario Orestes Aguirre González. "Photovoltaic solar energy: Conceptual framework." Renewable and Sustainable Energy Reviews 74 (2017): 590-601. https://doi.org/10.1016/j.rser.2017.02.081.

[10] Memon, Saim. "Investigating energy saving performance interdependencies with retrofit triple vacuum glazing for use in UK dwelling with solid walls, Sustainable Development on Building and Environment." In Sustainable Development on Building and Environment: Proceedings of the 7th International Conference, 2015. ISBN-13: 9780993120701. 
[11] Memon, Saim, and Philip C. Eames. "Heat load and solar gain prediction for solid wall dwellings retrofitted with triple vacuum glazing for selected window to wall area ratios." In World Renewable Energy Forum, WREF 2012, vol. 6, pp. 4636-4643. ASES, 2012. ISBN: 9781622760923

[12] Memon, Saim. "Analysing the potential of retrofitting ultra-low heat loss triple vacuum glazed windows to an existing UK solid wall dwelling." International Journal of Renewable Energy Development (IJRED) 3, no. 3 (2014): 161-174. https://doi.org/10.14710/ijred.3.3.161-174

[13] Memon, Saim, Farukh Farukh, Philip C. Eames, and Vadim V. Silberschmidt. "A new low-temperature hermetic composite edge seal for the fabrication of triple vacuum glazing." Vacuum 120 (2015): 73-82. https://doi.org/10.1016/j.vacuum.2015.06.024

[14] Memon, Saim. "Design, fabrication and performance analysis of vacuum glazing units fabricated with low and high temperature hermetic glass edge sealing materials." PhD diss., Loughborough University, 2013. https://dspace.lboro.ac.uk/2134/14562

[15] Fang, Yueping, Saim Memon, Jingqing Peng, Mark Tyrer, and Tingzhen Ming. "Solar thermal performance of two innovative configurations of air-vacuum layered triple glazed windows." Renewable Energy 150 (2020): $167-175$. https://doi.org/10.1016/j.renene.2019.12.115

[16] Katsura, Takao, Saim Memon, Ali Radwan, Makoto Nakamura, and Katsunori Nagano. "Thermal performance analysis of a new structured-core translucent vacuum insulation panel in comparison to vacuum glazing: Experimental and theoretically validated analyses." Solar Energy 199 (2020): 326-346. https://doi.org/10.1016/j.solener.2020.02.030

[17] Radwan, Ali, Takao Katsura, Saim Memon, Ahmed A. Serageldin, Makoto Nakamura, and Katsunori Nagano. "Thermal and electrical performances of semi-transparent photovoltaic glazing integrated with translucent vacuum insulation panel and vacuum glazing." Energy Conversion and Management 215 (2020): 112920. https://doi.org/10.1016/j.enconman.2020.112920

[18] Memon, Saim, and Philip C. Eames. "Design and development of lead-free glass-metallic vacuum materials for the construction and thermal performance of smart fusion edge-sealed vacuum glazing." Energy and Buildings (2020): 110430. https://doi.org/10.1016/j.enbuild.2020.110430

[19] Memon, Saim. "Thermal Conductivity Measurement of Vacuum Tight Dual-Edge Seal for the Thermal Performance Analysis of Triple Vacuum Glazing." Impact of Thermal Conductivity on Energy Technologies (2018): 133. http://dx.doi.org/10.5772/intechopen.74255

[20] Memon, Saim. "Experimental measurement of hermetic edge seal's thermal conductivity for the thermal transmittance prediction of triple vacuum glazing." Case studies in thermal engineering 10 (2017): 169-178. https://doi.org/10.1016/j.csite.2017.06.002

[21] Miao, Hong, Lingcong Zhang, Sixing Liu, Shanwen Zhang, Saim Memon, and Bi Zhu. "Laser Sealing for Vacuum Plate Glass with PbO-TiO2-SiO2-RxOy Solder." Sustainability 12, no. 8 (2020): 3118. https://doi.org/10.3390/su12083118

[22] Zhang, Shanwen, Min Kong, Saim Memon, Hong Miao, Yanjun Zhang, and Sixing Liu. "Thermal Analysis of a New Neutron Shielding Vacuum Multiple Glass." Sustainability 12, no. 8 (2020): 3083. https://doi.org/10.3390/su12083083

[23] Zhang, Shanwen, Min Kong, Hong Miao, Saim Memon, Yanjun Zhang, and Sixing Liu. "Transient temperature and stress fields on bonding small glass pieces to solder glass by laser welding: Numerical modelling and experimental validation." Solar Energy 209 (2020): 350-362. https://doi.org/10.1016/j.solener.2020.09.014

[24] Memon, Saim, Yueping Fang, and Philip C. Eames. "The influence of low-temperature surface induction on evacuation, pump-out hole sealing and thermal performance of composite edge-sealed vacuum insulated glazing." Renewable energy 135 (2019): 450-464. https://doi.org/10.1016/j.renene.2018.12.025

[25] Memon, Saim, Farukh Farukh, and Karthikeyan Kandan. "Effect of cavity vacuum pressure diminution on thermal performance of triple vacuum glazing." Applied Sciences 8, no. 9 (2018): 1705. https://doi.org/10.3390/app8091705

[26] Memon, Saim, and Philip C. Eames. "Predicting the solar energy and space-heating energy performance for solidwall detached house retrofitted with the composite edge-sealed triple vacuum glazing." Energy Procedia 122 (2017): 565-570. https://doi.org/10.1016/j.egypro.2017.07.419 
[27] Memon, Saim, and Philip C. Eames. "Solar energy gain and space-heating energy supply analyses for solid-wall dwelling retrofitted with the experimentally achievable U-value of novel triple vacuum glazing." Journal of Daylighting 4, no. 1 (2017): 15-25.

https://doi.org/10.15627/jd.2017.2

[28] Memon, Saim. "Design, development and thermal performance analysis of ultra-low heat loss triple vacuum glazing." In Solar World Congress 2017-Innovation for the 100\% renewable energy transformation. Abu Dhabi. (2017) ISBN 978-3-981 465 9-7-6. https://doi.org/10.18086/swc.2017.15.04

[29] Umrani, Zulfiqar. "Solar Energy: Challenges and opportunities in Pakistan." In 2017 International Conference on Innovations in Electrical Engineering and Computational Technologies (ICIEECT), pp. 1-1. IEEE, 2017. https://doi.org/10.1109/ICIEECT.2017.7916603

[30] Wakeel, Muhammad, Bin Chen, and Soomro Jahangir. "Overview of energy portfolio in Pakistan." Energy Procedia 88 (2016): 71-75.

https://doi.org/10.1016/j.egypro.2016.06.024

[31] ur Rehman, Waqas, Intisar A. Sajjad, Tahir N. Malik, Luigi Martirano, and Matteo Manganelli. "Economic analysis of net metering regulations for residential consumers in Pakistan." In 2017 IEEE International Conference on Environment and Electrical Engineering and 2017 IEEE Industrial and Commercial Power Systems Europe (EEEIC/I\&CPS Europe), pp. 1-6. IEEE, 2017. https://doi.org/10.1109/EEEIC.2017.7977733

[32] Qureshi, Tahir Masood, Kafait Ullah, and Maarten J. Arentsen. "Factors responsible for solar PV adoption at household level: A case of Lahore, Pakistan." Renewable and Sustainable Energy Reviews 78 (2017): 754-763. https://doi.org/10.1016/j.rser.2017.04.020

[33] Makeen, Peter, Hani A. Ghali, and Saim Memon. "Experimental and Theoretical Analysis of the Fast Charging Polymer Lithium-Ion Battery Based on Cuckoo Optimization Algorithm (COA)." IEEE Access 8 (2020): 140486140496 https://doi.org/10.1109/ACCESS.2020.3012913

[34] Khan, Asif, Saim Memon, and T. P. Sattar. "Integration and management of solar energy for electric vehicle charging station." In Solar World Congress 2017-Innovation for the 100\% renewable energy transformation. Abu Dhabi, (2017). ISBN 978-3-981 465 9-7-6. https://doi.org/10.18086/swc.2017.16.03

[35] Khan, Asif, Saim Memon, and Tariq Pervez Sattar. "Analyzing integrated renewable energy and smart-grid systems to improve voltage quality and harmonic distortion losses at electric-vehicle charging stations." IEEE Access 6 (2018): 26404-26415. https://doi.ord/10.1109/ACCESS.2018.2830187

[36] Hussain, Anwar, Muhammad Rahman, and Junaid Alam Memon. "Forecasting electricity consumption in Pakistan: The way forward." Energy Policy 90 (2016): 73-80. https://doi.org/10.1016/j.enpol.2015.11.028

[37] Zhou, Deyi, Tariq Shah, Khalil Jebran, Sajjad Ali, and Asad Ali. "Acceptance and willingness to pay for solar home system: Survey evidence from northern area of Pakistan." Energy Reports 3 (2017): 54-60. https://doi.org/10.1016/j.egyr.2017.03.002

[38] Adnan, Shahzada, Azmat Hayat Khan, Sajjad Haider, and Rashed Mahmood. "Solar energy potential in Pakistan." Journal of Renewable and Sustainable Energy 4, no. 3 (2012): 032701. https://doi.org/10.1063/1.4712051

[39] Farooqui, Suhail Zaki. "Prospects of renewables penetration in the energy mix of Pakistan." Renewable and Sustainable Energy Reviews 29 (2014): 693-700. https://doi.org/10.1016/j.rser.2013.08.083.

[40] Amer, Muhammad, and Tugrul U. Daim. "Selection of renewable energy technologies for a developing county: a case of Pakistan." Energy for sustainable development 15, no. 4 (2011): $420-435$. https://doi.org/10.1016/j.esd.2011.09.001.

[41] Ahmed, M. Akhlaque, Ahmad Firoz, and M. Wasim Akhtar. "Estimation of global and diffuse solar radiation for Hyderabad, Sindh, Pakistan." Journal of Basic \& Applied Sciences 5, no. 2 (2009): 73-77. ISSN: 1814-8085.

[42] Ahmed, M. Akhlaque, Firoz Ahmed, and A. W. Akhtar. "Distribution of total and diffuse solar radiation at Lahore, Pakistan." Journal of Scientific Research 40, no. 1 (2010): 37-43. ISSN 0555-7674.

[43] Mirza, Umar K., Nasir Ahmad, Tariq Majeed, and Khanji Harijan. "Wind energy development in Pakistan." Renewable and Sustainable Energy Reviews 11, no. 9 (2007): 2179-2190. https://doi.org/10.1016/j.rser.2006.03.003 
[44] Hara, Shigeomi, Makoto Kasu, and Noriaki Matsui. "Estimation method of solar cell temperature using meteorological data in mega solar power plant." IEEE Journal of Photovoltaics 6, no. 5 (2016): 1255-1260. https://doi.org/10.1109/JPHOTOV.2016.2589363

[45] Ilahi, Tehseen, Muhammad Abid, and Touseef Ilahi. "Design and analysis of thermoelectric material based roof top energy harvesting system for Pakistan." In 2015 Power Generation System and Renewable Energy Technologies (PGSRET), pp. 1-3. IEEE, 2015.

https://doi.org/10.1109/PGSRET.2015.7312207

[46] Kaushik, S. C., K. R. Ranjan, and N. L. Panwar. "Optimum exergy efficiency of single-effect ideal passive solar stills." Energy efficiency 6, no. 3 (2013): 595-606.

https://doi.org/ 10.1007/s12053-013-9194-x

[47] Bounechba, Hadjer, Aissa Bouzid, Hamza Snani, and Abderrazak Lashab. "Real time simulation of MPPT algorithms for PV energy system." International Journal of Electrical Power \& Energy Systems 83 (2016): 67-78. https:/doi.org/10.1016/j.ijepes.2016.03.041.

[48] Khalil, Hafiz Bilal, and Syed Jawad Hussain Zaidi. "Energy crisis and potential of solar energy in Pakistan." Renewable and Sustainable Energy Reviews 31 (2014): 194-201.

https://doi.org/10.1016/j.rser.2013.11.023

[49] Shaker, Hamid, Hamidreza Zareipour, and David Wood. "Estimating power generation of invisible solar sites using publicly available data." IEEE Transactions on Smart Grid 7, no. 5 (2016): 2456-2465. https://doi.org/10.1109/TSG.2016.2533164.

[50] Vadiee, Amir, Mahmoud Yaghoubi, Viktoria Martin, and Yousef Bazargan-Lari. "Energy analysis of solar blind system concept using energy system modelling." Solar Energy 139 (2016): $297-308$. https://doi.org/10.1016/j.solener.2016.09.039

[51] Villalba, Ayelén, Erica Correa, Andrea Pattini, and Daniel Vicare. "Hot-cool box calorimetric determination of the solar heat gain coefficient and the U-value of internal shading devices." Energy efficiency 10, no. 6 (2017): 15531571.

https://doi.org/10.1007/s12053-017-9544-1

[52] Kılkış, Şiir. "A nearly net-zero exergy district as a model for smarter energy systems in the context of urban metabolism." Journal of Sustainable Development of Energy, Water and Environment Systems 5, no. 1 (2017): 101126.

https://doi.org/d5.0136

[53] He, Guannan, Qixin Chen, Chongqing Kang, and Qing Xia. "Optimal offering strategy for concentrating solar power plants in joint energy, reserve and regulation markets." IEEE Transactions on sustainable Energy 7, no. 3 (2016): 1245-1254. https://doi.org/10.1109/TSTE.2016.2533637

[54] Sera, Dezso, Remus Teodorescu, and Pedro Rodriguez. "PV panel model based on datasheet values." In 2007 IEEE international symposium on industrial electronics, pp. 2392-2396. IEEE, 2007. https://doi.org/10.1109/ISIE.2007.4374981

[55] De Soto, Widalys, Sanford A. Klein, and William A. Beckman. "Improvement and validation of a model for photovoltaic array performance." Solar energy 80, no. 1 (2006): 78-88. https://doi.org/10.1016/j.solener.2005.06.010

[56] Swaraj, Kumar, Abhimanyu Mohapatra, and Sudhansu Sekhar Sahoo. "Combining PV MPPT algorithm based on temperature measurement with a PV cooling system." In 2016 International Conference on Signal Processing, Communication, Power and Embedded System (SCOPES), pp. 482-489. IEEE, 2016. https:/doi.org/10.1109/SCOPES.2016.7955876

[57] Dubey, Swapnil, Jatin Narotam Sarvaiya, and Bharath Seshadri. "Temperature dependent photovoltaic (PV) efficiency and its effect on PV production in the world-a review." Energy Procedia 33 (2013): $311-321$. https://doi.org/10.1016/j.egypro.2013.05.072

[58] Zondag, H. A. "Flat-plate PV-Thermal collectors and systems: A review." Renewable and Sustainable Energy Reviews 12, no. 4 (2008): 891-959.

https://doi.org/10.1016/j.rser.2005.12.012

[59] Žandeckis, A., V. Kirsanovs, M. Dzikēvičs, and K. Kḷviṇa. "Performance simulation of a solar-and pellet-based thermal system with low temperature heating solutions." Energy Efficiency 10, no. 3 (2017): 729-741. https://doi.org/10.1007/s12053-016-9482-3

[60] Vivar, M., M. Fuentes, J. Castro, and R. García-Pacheco. "Effect of common rooftop materials as support base for solar disinfection (SODIS) in rural areas under temperate climates." Solar energy 115 (2015): 204-216. https://doi.org/10.1016/j.solener.2015.02.040 
[61] Kayo, Genku, and Nobue Suzuki. "On-site Energy Management by Integrating Campus Buildings and Optimizing Local Energy Systems-Case Study of the Campus in Finland." Journal of Sustainable Development of Energy, Water and Environment Systems 4, no. 4 (2016): 347-359. https://doi.org/10.13044/j.sdewes.2016.04.0027

[62] Memon, Saim. "Advanced Thermoelectric Materials for Energy Harvesting Applications." .IntechOpen Publisher, London, ISBN: 978-1-78984-529-7, (2020). https://doi.org/10.5772/intechopen.77430

[63] Memon, Saim, and Khawaja Noman Tahir. "Experimental and analytical simulation analyses on the electrical performance of thermoelectric generator modules for direct and concentrated quartz-halogen heat harvesting." Energies 11, no. 12 (2018): 3315. https://doi.org/10.3390/en11123315

[64] Memon, Saim. "Introductory Chapter: Introduction to Advanced Thermoelectric Materials for Energy Harvesting Applications", Advanced Thermoelectric Materials for Energy Harvesting Applications, IntechOpen, London. (2019).

https://doi.org/10.5772/intechopen.89640

[65] Memon, Saim, Maekele Mihreteab, Takao Katsura, Ali Radwan, Shanwen Zhang, Ahmed A. Serageldin, and Essam M. Abo-Zahhad. "Experimental and theoretical performance evaluation of parabolic trough mirror as solar thermal concentrator to thermoelectric generators." International Journal of Solar Thermal Vacuum Engineering 1, no. 1 (2020): 22-38. ISSN online (2716-6953).

https://doi.org/10.37934/stve.1.1.2238 